\title{
EchoGéo
}

48 | 2019

Illegal cannabis cultivation in the world

\section{American Weed: A History of Cannabis Cultivation in the United States}

Nick Johnson

\section{(2) OpenEdition \\ 12 Journals}

Electronic version

URL: https://journals.openedition.org/echogeo/17650

DOI: 10.4000/echogeo.17650

ISSN: 1963-1197

\section{Publisher}

Pôle de recherche pour l'organisation et la diffusion de l'information géographique (CNRS UMR 8586)

\section{Electronic reference}

Nick Johnson, "American Weed: A History of Cannabis Cultivation in the United States", EchoGéo [Online], 48 | 2019, Online since 13 July 2019, connection on 21 September 2021. URL: http:// journals.openedition.org/echogeo/17650 ; DOl: https://doi.org/10.4000/echogeo.17650

This text was automatically generated on 21 September 2021.

EchoGéo est mis à disposition selon les termes de la licence Creative Commons Attribution - Pas d'Utilisation Commerciale - Pas de Modification 4.0 International (CC BY-NC-ND) 


\section{American Weed: A History of Cannabis Cultivation in the United States}

Nick Johnson

\section{Introduction: Marijuana Menaces the Midway}

1 In the summer of 1929, Reefer Madness descended upon the Windy City. In late April, the Illinois house of representatives had passed a bill to ban "loco-weed," a plant whose "Mexican form" was "marijuana," a "narcotic" (Brown, 1929a) ${ }^{1}$ Two months later, as the bill languished in the senate, the Chicago Tribune ran an article and accompanying back-page photo on marijuana, attempting to spur the legislature into action. The paper claimed that the "dangerous, habit forming drug" had been "introduced a dozen years ago or so by Mexican laborers" and was now spreading across the city, ensnaring "thousands of workingmen," "youths and girls," as well as "school children." (Chicago Tribune, 1929a). In the photo, two dark-skinned men with sun hats are crouched next to some cannabis plants "in the southern part of the city," "gathering marijuana" while the "legislature delays action" (Chicago Tribune, 1929b; Falck, 2010, p. 80-81).

2 The newspaper clearly intended the photo to be visual proof of marijuana's "Mexican" origins, as well as a swipe at the legislature for stalling while devious foreigners harvested a dangerous drug. The accompanying article claimed that cannabis "seeds" were "brought by Mexicans" and "planted in tiny patches near the box car homes of the laborers." But if Mexicans were blamed for the drug's introduction, the rest of the article made clear that they could hardly be held responsible for its spread. In addition to naming two "alleged sellers of marijuana cigarets" as "Harry Johnson" and "Richard Drake," the report also claimed that marijuana smoking was widespread "in South Chicago, in Blue Island, in Kensington, and other outlying districts, and it can be purchased in restaurants, drug stores, and poolrooms" - all of which were not exclusively the domain of Mexicans (Chicago Tribune, 1929a). Nature, too, helped the 
"loco weed" spread across the city; not only was marijuana said to be "easily grown in this climate," but "the seed of the plant is used as bird seed" and could thus be distributed by birds as well as drug dealers (Chicago Tribune 1929a; Falck, 2010, p. 85-86; Duvall, 2015: 110; Johnson, 2017a, p. 43-47).

3 Clearly, many factors contributed to marijuana's spread across Chicagoland in the late 1920s. So why did the Tribune decide to run a photo of two Mexicans harvesting cannabis instead of, say, mugshots of the alleged dealers it mentions in the article?

\section{A Mexican Connection? Theories and Themes in US Cannabis History}

4 Answering that question requires engaging one of the most prominent theories of cannabis history in the United States. One popular history of the plant dubbed it the "Mexican connection," while a cannabis historian recently addressed it as the "Mexican hypothesis" (Lee, 2012, p. 38; Campos, 2018, p. 6). This theory holds that Mexicans were primarily responsible for the introduction and spread of smoked cannabis flower thereafter called by its Mexican name, "marijuana" - and that racism toward Mexican immigrants prompted cannabis prohibition at the state and federal level. Many cannabis histories present this theory as established truth (Bonnie and Whitebread, 1974, p. 32-37; Lee, 2012, p. 38-39; Warf, 2014, p. 429; Duvall, 2015, p. 108; Barcott, 2015, p.19-20; Hudak, 2016, p.37-38). However, recent scholarship argues that the relationship between Mexicans and cannabis in the United States was far more nuanced than is typically suggested, and that prohibition was driven by other factors in addition to racism (Johnson, 2017a, p.17-35; Johnson, 2017b; Rathge, 2018; Campos, 2018, p. 26-29). This scholarship also suggests that while Mexicans were clearly involved in the early American marijuana trade, their responsibility for "introducing" the practice of smoking marijuana was not as clear-cut as earlier works implied (Campos, 2018, p. 17-19; Rathge, 2018).

5 Here, the Chicago Tribune's coverage seems to support arguments both for and against the Mexican connection. On the one hand, many of Chicago's Mexicans did reside in socalled "boxcar camps," (Flores, 2018) and although marijuana was not all that popular in Mexico, its documented presence among the "lower classes" (Campos, 2012, p. 90-94) and laborers makes it entirely plausible that some would plant or harvest it, whether for their own use or to make an extra buck (Johnson, 2017b). On the other hand, it is possible that the Chicago Tribune ran the Mexican photograph to exoticize the plant, playing on anti-Mexican sentiment already prevalent in Chicago and Springfield (Falck, 2010, p. 86-87; Gutiérrez, 1995, p. 55, 72; Flores, 2018). The two men in the photo are clearly picking cannabis, but what they planned to do with it afterwards is not clear was it for personal or local use, or did they intend to sell it, as the caption implies? It is also hard to tell from the photograph whether the plants were cultivated or feral, which casts some doubt on the article's claim that Mexicans "planted" marijuana seeds near their "box car homes." Finally, the article certainly implicates many more neighborhoods and occupations in the marijuana trade beyond "Mexican laborers."

6 For its part, the Illinois legislature did not share the Tribune's urgency. The "anti-loco weed" bill eventually passed the senate committee, but Governor Louis Emmerson vetoed it, heeding a warning from the Illinois Pharmaceutical Association that a 
cannabis ban "might stop the sale of certain cough and corn cures and even interfere with the sale of standard bird seed." (Brown, 1929b). Illinois did eventually follow the lead of dozens of other states and outlaw cannabis in 1931, six years before national prohibition came via the Marijuana Tax Act (Bonnie and Whitebread, 1974, p. 32).

\section{Putting the Grass in "Grass": Centering the Environment in Cannabis History}

7 The Tribune's 1929 marijuana coverage might not do much to settle the scholarly debate over the "Mexican connection," but it offers a useful starting point to consider some of the most important themes in US cannabis history - not only the plant's broad association with Mexicans, minorities, and the working class, but also the illicit planting of marijuana and other agricultural concerns, the conflation of hemp and marijuana, and the proliferation of feral cannabis. These themes are evident in the Tribune articles and scores of similar sources, but the existing literature on cannabis in the United States has largely overlooked them in favor of attempts to explain movements for prohibition and legalization (Bonnie and Whitebread, 1974; Sloman, 1979; Herer, 1985; Gieringer, 1999; Ferraiolo, 2007; Lee, 2012; Hecht, 2014; Barcott, 2015; Dufton, 2017). Despite a few, mostly recent exceptions (Falck, 2010; Rendon, 2012; Johnson, 2017a), scholars have generally not been willing to consider aspects of cannabis history beyond the political or social concerns wrought by use of the plant's products, be they drugs or rope. In the same way that cannabis scholars are now offering a welcome reassessment of the previously unchallenged "Mexican connection," I believe it is also time for a broader reassessment of how we investigate the history of the plant.

8 The focus on marijuana's political and social history is understandable for contemporary as well as historical reasons, and many of the books and articles that address it are excellent and useful. Nevertheless, there is considerable opportunity to push the literature forward so it can address questions for which the current historiography fails to provide satisfying answers. Why and how, for example, did cannabis (the plant) spread across the country? Why and how did people cultivate it? How did cultivation change over time, and what were the effects of those changes? Why and how did law enforcement attempt to eradicate cannabis - whether feral or cultivated, and what were the effects of those attempts? These are questions that move the line of inquiry away from social and political history and toward environmental history, where scholars may gain a more complete understanding of this human-plant relationship. Indeed, far from ignoring social or political history, environmental history deepens our understanding of both (Crosby, 1972; Worster, 1979; Cronon, 1992; Merchant, 2003; Nash, 2007; Ecrie, 2013).

\section{Pot of a Bigger Picture: Testing the Regional Analysis in Cannabis History}

9 In addition to offering a starting point for more environmentally focused studies, this article tests the usefulness of another popular approach to US cannabis history - the regional or local analysis. This approach has considerable precedence in the literature, 
including my own work (Mosk, 1939; Hopkins, 1951; Raphael, 1985; Brady, 2013; Hecht, 2014; Johnson, 2017a; Rathge, 2018), so I was curious as to whether experiences with the plant differed in other major regions, as well as whether a comparative regional analysis was a useful model for telling the plant's story in the United States. Accordingly, this article explores environmental aspects of American cannabis history across three distinct regions of the country - the West, South, and Midwest ${ }^{2}$. I argue that while there may be some unique regional experiences with cannabis, both the ways in which the plant spread across those regions and the response to that spread were remarkably consistent. Thus, individual regional analyses may prove useful in some respects, but in general they do not offer the most accurate framework for understanding cannabis in the US.

Instead, I submit that a more macro-scale approach to the plant's history - one that identifies broader themes pulled from a multitude of state, local, and regional experiences - might help put critical questions of the plant's history and historical geography to bed. For instance, it might be easier to interrogate theories about cannabis's association with ethnic minorities, including Mexicans, when we consider a more geographically diverse set of sources. Likewise, it is easier to understand how the United States become one of the world's premier centers of cannabis cultivation when we consider the fact that indoor cannabis farming boomed all over the country in the 1980s and 1990s, not just in California or other states where cannabis was gaining increased acceptance. When we consider that local authorities enlisted farmers and citizens in "noxious weed" campaigns against feral cannabis, the extent to which the plant embedded itself within traditional American agriculture becomes clear. Finally, one can only perceive the massive level of chemical use during the government's war on marijuana during the 1970s and 1980s by looking at eradication efforts in many states, not just "ground zeros" like northern California (Miller, 2018, p. 13-109).

By highlighting these and other themes in the American context, this article presents an abridged example of a different kind of cannabis history, one that need not only be applied to US-based scholarship. Indeed, there is already precedent for environmental cannabis history beyond the United States (McNeill, 1992). My hope is that this article will encourage further investigation of cannabis along those lines, so that we may better understand humanity's experience with one of the modern world's most controversial crops.

\section{Early Cannabis History in the United States}

12 There are two main types of cannabis in the world - that grown for fiber and other industrial purposes, commonly referred to as "hemp," and that grown for drugs, commonly known as "marijuana" (McPartland, 2017). Famously, hemp was the first type of cannabis cultivated in what became the United States. From the early seventeenth through the nineteenth centuries, hemp could be found all over the American colonies and the fragile nation that emerged from them. Prominent early sites of hemp cultivation included the Jamestown Colony and the Virginia farms of George Washington and Thomas Jefferson.

13 By the time Kentucky joined the union in 1792, the Bluegrass State was already the nation's leading hemp producer. There, hemp was inextricably bound with the institution of slavery; not only did slaves perform the difficult and essential labor of 
harvesting and breaking the hemp crop, but the resulting rope and twine was used to tie bales of slave-produced cotton (Hopkins 1951). The American hemp industry peaked before 1860 and declined with the loss of slave labor and the rise of metal baling clasps and new fiber crops after the Civil War (Hopkins, 1951; Evans, 2007).

Meanwhile, drug cannabis had made its way into the American pharmacopoeia by 1851 , though its use in medicine was sporadic and ill-defined (Johnson, 2017, p. 21-24) ${ }^{3}$. Often referred to as "Indian hemp" or "cannabis indica," most early cannabis drugs were imported from India via Britain. By the early 1900s, however, the US government began experimenting with the domestic production of certain imported drugs, including cannabis (Stockberger, 1919). Many of these agricultural experiments cropped up in the South, where the soil and climate were thought to be ideal for drug cultivation (Stockberger, 1915, p. 19).

\section{Muggles and Minorities: A Muddled Theory}

Around the same time, the practice of smoking marijuana appeared in the United States. Exactly when and how it was introduced is unclear, but most early reports of marijuana smoking come from two main areas: the Southwest, where local reports claimed it was introduced by Mexicans, and the port of New Orleans, which became "one of the earliest urban markets for illicit marijuana use" (Rathge, 2018). Reports of "marijuana," a "Mexican" drug, began to appear from cities and towns in New Mexico, Arizona, and Texas (Johnson, 2017a, p. 17, 26-28). Of course, the drug was not new at all; "marijuana" was simply the smoked version of the well-known medicinal compound "cannabis indica," which was sold in pharmacies, both in flower and tincture form (Campos, 2018, p. 22). In 1915, motivated by an alleged Mexican dope menace, the city of El Paso, Texas, became the first US municipality to ban the nonmedical cannabis trade (El Paso Herald, 1915).

Importantly, marijuana use did not appear to be especially common in Mexican immigrant communities, and a Mexican presence did not always lead to cannabis bans in the West (Campos, 2018, p. 14). In 1913 California became the first state to ban the trade in nonmedical cannabis. That law, however, had less to do with the state's large Mexican population than it did with broader efforts to curb all kinds of vice activity during the Progressive Era (Gieringer, 1999). Colorado's 1917 cannabis ban was likely a result of the same Progressive sentiment, as complaints about "Mexican marijuana" do not show up in the state's newspapers until the 1920s (Johnson, 2018).

Meanwhile, by 1920, reports from New Orleans referred to marijuana - often using its street name, "muggles" - as a "Mexican" drug, and city police seized several large shipments of marijuana on Mexican ships. The average Crescent City user, however, was young and white, and a historian of the New Orleans marijuana trade points out that there was little effort on behalf of either newspapers or city officials to target Mexicans as the source of what they considered to be a deadly and addictive vice (Rathge, 2018). The same went for blacks, who, contrary to claims made in an earlier cannabis history, comprised only a small number of marijuana arrests in the city between 1920 and 1930 (Rathge, 2018; Bonnie and Whitebread, 1974, p. 42-43).

Wherever it originated, the practice of marijuana smoking spread rapidly during the 1920s, especially in industrial hubs like Kansas City and Chicago. By the 1930s, a small population of Mexican laborers grew marijuana on farms and rural spaces across the 
American West (Johnson, 2017). Meanwhile, jazz musicians like Louis Armstrong brought "reefers" to various gigs across the country, provoking outrage in many cities (Falck, 2010, p. 81-82; Lee, 2012, p. 9-14).

Reports associating marijuana with Mexicans increased amidst growing anti-Mexican and anti-immigrant sentiment in the 1920s (Parrish, 1992, p. 109-122; Gutiérrez, 1995, p. 71-73). In 1927, Ray Talbot, a Colorado state representative from Pueblo, declared that " 20 to 40 percent" of the city's high school students used "marijuana," which he asserted was "grown in large quantities by Mexicans in their backyard" (Denver Post, 1927). Talbot failed to note any specific "Mexican" peddler, and he tried to blame Mexican marijuana for the death of one student even though local newspaper coverage indicated that the young man died "following a short illness" (Pueblo Chieftain, 1926a; Pueblo Chieftain, 1926b). Also in 1927, police in Gary, Indiana, broke up a "quarrelsome" group of young people at a hotel and learned that they had been "smoking cigarets impregnated with marijuana" (Chicago Tribune, 1927). After learning that the youths had been sold some "reefers," they then arrested "three Mexicans" who "admitted the traffic"; the report does not make clear, however, how police traced the specific transaction back to these three men. Even if the men had sold some joints to the teens, that act alone would hardly constitute "a systematic effort to enslave high school students to marijuana," as the Chicago Tribune asserted.

If marijuana reports from the Midwest and West tended to focus on Mexicans during the 1920s, reports from the South affirmed the plant's association with a broad spectrum of the working-class, youth, and other minorities. In Nashville, for instance, marijuana was said to be used by "society people, musicians, and many negroes" (The Tennessean, 1936). In Atlanta, it was "gaining many converts among the high school students... and also in the negro sections of the city" (Atlanta Constitution, 1935) In Greensboro, North Carolina, marijuana found "growing in an apartment house windowbox" was determined to be "a source of the marijuana cigarettes that are said to have gained many victims among the young of that city" (News-Record, 1935).

21 The claims in these reports about typical marijuana users were likely passed on from law enforcement and not fact-checked by newspaper reporters. ${ }^{4}$ When faced with reports like the 1929 Chicago Tribune article, which mentioned a wide range of marijuana users, it is difficult to accept that cannabis was popular only among Mexicans in Gary, "musicians" in Nashville, or "negro sections" in Atlanta. In addition, like Talbot's baseless assertions in Colorado, most reports claiming a rash of marijuanaaddicted youth relied on hearsay and offered little actual evidence. Indeed, in 1937 a representative from the American Medical Association challenged this widespread notion at the hearings for the Marijuana Tax $\mathrm{Act}^{5}$.

There is enough evidence to say that the nation's earliest marijuana users were broadly working-class, but we cannot say much more than that. Instead, reports from disparate regions point to the cosmopolitan nature of cannabis consumers, complicating simplistic or local narratives that hinge on the plant's association with minority communities. They also confirm historian Zach Falck's argument that "cannabis was desirable, useful, and valuable" to a wide range of users and "cultivators" (Falck, 2010, p. 85). These "cultivators" - and their weedy crop - are the subjects of the next section. 


\section{Forbidden Farms: Early Illicit Cultivation} Most of the marijuana in the United States was likely imported from Britain for the pharmaceutical industry, with Mexico, Central America, or the Caribbean as other potential sources (Rathge, 2018; Campos, 2018; Abel, 1982; Beach, 2016; Rubin and Comitas, 1976; Angrosino, 2003). In the South, reports of illegal cultivation from this period are especially rare and often involved a small number of plants (News-Record, 1935; The Times, 1930; Tennessean, 1936b). In the West, where expansive irrigation projects drew large agricultural work forces and created ample habitat for cannabis, Mexican sugar beet workers were caught growing pot in Montana and Wyoming (Billings Gazette, 1931; Helena Independent, 1933; Billings Gazette, 1935) ${ }^{7}$. Californians, too, produced illegal bumper crops in the 1930s (Woodland Daily Democrat, 1934; Bakersfield Californian, 1938). Still, large-scale grows remained few and far between until decades later.

\section{Weeds Gone Wild: The Intractable "Problem" of Feral Cannabis}

In addition to illicit cultivators, authorities increasingly targeted so-called "wild marijuana." This trend, which began after the tax act and would continue through the 1980s, was based on the largely incorrect assumption that any cannabis plants would or could be made to produce marijuana. Most of the "wild" marijuana" authorities destroyed or worried about was either non-psychoactive hemp or feral varieties of marijuana that are far less potent than a cultivated plant (Clarke and Merlin, 2013, p. 52). The Tax Act stipulated that producers of hemp birdseed must sterilize their product before it went to market, lest it sprout into harvestable "marijuana" (Johnson, 2017, p. 54-57; Daily Press, 1939). But in the three years prior to the Tax Act, the American oilseed industry imported some 193 million pounds of (unsterilized) hemp seed, ensuring that sterilization would not prevent birds and other wildlife from spreading hemp. ${ }^{8}$

Authorities everywhere were concerned about stray cannabis, but in the early years of prohibition this concern was remarkably acute in the Midwest ${ }^{9}$. Midwestern authorities tasked with eradicating so-called "wild marijuana" quickly realized what they were up against and began recruiting local citizens to help locate and destroy cannabis. In rural areas, this deputizing was often carried out in the context of "noxious weed" removal, which would have been familiar to farmers and rural residents all over the country (Timmons, 2005, p. 753; Fiege, 2005). Officials in Polk County, Iowa, appointed "weed 
commissioners" specifically tasked with helping federal agents eliminate marijuana, which "may be classed as among the 'noxious' weeds" in state law (Des Moines Register, 1938). The Wisconsin legislature considered a bill "to declare marihuana a noxious weed" (Chippewa Herald Telegram, 1938). In Illinois, De Kalb County farmers were asked to look for cannabis "in the corners of their fields where weeds usually thrive," and "members of the noxious weed committee" in Whiteside County met with a federal narcotics agent after county supervisors agreed to help stamp out feral cannabis (True Republican, 1938a; 1938b; 1938c). This occurred despite the fact that Illinois state laws did "not provide for the forced destruction of marijuana" and did "not classify it as a noxious weed" (Weekly Review, 1938).

In Illinois and other Midwestern states, though, laws compelling citizens to take part in anti-marijuana drives proved to be totally unnecessary. At the urging of newspapers, officials, or law enforcement, citizens in at least four Midwestern states voluntarily participated in annual or one-off eradication campaigns from 1938 to 1941. Weedwhacking Samaritans included farmers and volunteer groups in Illinois (True Republican, 1938c; 1940a; 1940b) and Indiana (The Times, 1938), newspaper reporters in Michigan (The Saline Observer, 1938), and the American Legion in Minnesota (Minneapolis Star, 1938). In Michigan, the Ludington Daily News tried to involve the entire citizenry, breathlessly pleading for not only farmers but "Sunday drivers, Boy Scouts and Girl Scout groups and country hikers... every man, woman, and child" to be on the lookout for marijuana (Ludington Daily News, 1940).

With so many willing participants, some of these public drives against feral cannabis found modest success. In northwestern Illinois, farmers, law enforcement, and the De Kalb County Volunteers reportedly reduced De Kalb County's stray marijuana crop from 200 acres (about 81 hectares) to "a few isolated patches" in just over a year (True Republican, 1940b). By the end of 1938, the police-public alliance in Davenport, Iowa, managed to uproot more than three tons of cannabis (Quad City Times, 1939); that same year, anti-cannabis forces destroyed 2,188 tons (1,984 metric tons) of plant material in Wisconsin (Oshkosh Northwestern, 1939). In all, federal narcotics agents eliminated some 26,000 tons (23,586 metric tons) of feral cannabis across the country in 1938, much of it with the public's help (Oshkosh Northwestern, 1939). It is difficult to put these numbers into context, but it probably does not matter; cannabis was so successful in the American landscape that for every plant authorities ripped up, many more were surely growing, seeding, or sprouting somewhere else.

Concern about feral cannabis stemmed from the belief that if the plant was left to grow in its natural state, a shadowy class of users and dealers would eventually come by and "harvest" the illegal drug. Sometimes these fears were simply xenophobic, like when an Illinois paper claimed in 1938 that "a certain element among the foreign residents may take advantage of the situation" (True Republican, 1938c). Much, if not most of the time, this fear was chemically unsubstantiated, as the plants in question likely sprang from hempseed carried by birds or the wind. Actual reports of people harvesting feral marijuana are extremely rare before World War II, but they are more frequent in the decades that followed, as wartime hemp cultivation increased the population of feral cannabis and the counterculture swelled the ranks of those searching for it. 


\section{Hemp for Victory} Moines Register, 1942). Indiana's 1943 target was 20,000 acres (about 8,000 hectares) (Indianapolis News, 1942), but Hoosiers only planted around 8,000 (Maddox, 1943), while Wisconsinites planted 31,000 (Leader-Telegram, 1943). After securing commitments from hundreds of local farmers, the US government built hemp processing plants in dozens of tiny towns across the rural Midwest (Lafayette Journal and Courier, 1943; Belvidere Daily Republican, 1943; St. Cloud Times, 1944; Marshfield News Herald, 1944). Unsurprisingly, the government found it far easier to grow hemp than eradicate it; the nation reportedly grew some 226,000 acres (about 90,000 hectares) in 1943, making the Hemp for Victory campaign a resounding success (Leader-Telegram, 1943). surplus hemp in 1943 that it had to pay American cord manufacturers to "absorb a portion of the domestic hemp supply" (Humboldt Independent, 1944). As the end of the war drew near, the government tried to gradually reduce the nation's hemp acreage and use every last bit of fiber it produced. However, having reaped the rewards of a humming wartime industry (Globe Gazette, 1944; Daily Chronicle, 1944), many rural Midwesterners were not ready to watch hemp prices fall or see job-providing hemp plants shuttered (Marshfield News Herald, 1944; The Brook Reporter, 1944; Chicago Tribune, 1944). By 1944, War Hemp Industries, Inc. - the company that managed the government hemp plants during the war - expected "at least a moderate revival of the industry" (The Times Herald, 1944) and noted that "farmers and townsmen at 42 government hemp mill locations in the [M]idwest would welcome a return to a hemp growing program" (The Pantagraph, 1945b). Company executives pointed to new machinery and production methods that would allow the US to "produce hemp cheaper than... any place else in the world" (Asheville Citizen-Times, 1944). In August 1945, veterans of the wartime hemp industry organized the American Fibers Industries, Inc., a cooperative dedicated to sustaining the industry in America. The group claimed hemp would bring $\$ 60$ million in wages for "farmers, mill workers, and processors" (St. Cloud Times, 1945).

Alas, the highly anticipated revival of the US hemp industry never happened. The government resumed hemp imports from Latin America and the Caribbean in 1944 (Chicago Tribune, 1944; Council Bluffs Nonpareil, 1944), and from the Philippines in 1945 (Post-Crescent, 1945); meanwhile, domestic hemp prices collapsed with the removal of 
wartime price supports (Courier-Post, 1954). And of course, there was the issue of all those hemp plants being possible sources of "marijuana." In 1945, the US Treasury Department ordered Wisconsin hemp growers to "remove the leaves and flowers before sending their product to the mills" (Chippewa Herald-Telegram, 1945). Irate farmers protested, arguing that "such a process would not only injure the plant but would be so costly there would be no point in growing it." To continue raising hemp profitably, the state's farmers needed an exemption in the Marijuana Tax Act to allow "hemp to be transported tax-free to the mills"; they got no such modification, and the domestic hemp industry sputtered out (Chippewa Herald-Telegram, 1945).

\section{Postwar Bumper Crops}

With the decline of the wartime hemp industry came the resurgence of the "marijuana menace." During the war, federal narcotics agents were generally reluctant to raid cannabis farms, but afterward they resumed these raids with trademark intensity. In the West, where wartime production resulted in explosive population growth, there was a ready market for all kinds of illicit pastimes, including pot. Denver, for instance, saw an uptick in marijuana traffic and so-called "marijuana dens" - secret places where people would buy and/or smoke the drug. Although most marijuana was still being smuggled in from Mexico and other countries, a growing base of illegal cultivators found the sprawling cities and farmland of the West quite amenable to cannabis farming. In Colorado and California, two states that experienced huge population spikes during the war, authorities found some of the largest postwar marijuana farms in the country. A survey of eleven California newspapers between 1950 and 1960 yielded no fewer than 103 reports of cannabis growing somewhere in the state, whether feral or cultivated. The relative paucity of cultivation reports from other states over the same period suggest that illegal growers in Colorado and California were among the leading producers of domestic marijuana between 1945 and $1960^{11}$.

In the 1960s, cannabis was adopted by the counterculture - that nebulous, youthinfused movement that grew out of the 1950s beatnik scene and swept the nation, protesting the Vietnam War, marching for Civil Rights, and generally resisting the conformist, consumerist nature of postwar America (Johnson, 2017, p. 86-92; Lee, 2012, p. 66-79). Beats, hippies, back-to-the-landers, and other counter-culturalists made no attempts to hide their affinity for marijuana, and American soldiers sampled Thai and Vietnamese varieties to stave off the boredom and horror of war in Southeast Asia (Kuzmarov, 2009). While many American pot smokers still mostly relied on drug smugglers, many apparently took to plucking the residual fruits of the US government's wartime hemp industry.

Uncultivated cannabis produces very little THC (Clarke and Merlin, 2013, p. 51), the major psychoactive compound in marijuana. The hemp produced on Midwestern farms in the 1940s had only trace amounts of it, insufficient for a buzz. Still, it is possible that the escaped progeny of those hemp plants expressed natural genetic variation and began producing small amounts of $\mathrm{THC}^{12}$. To produce a psychoactive effect, the THC content of the female flowers only needs to be in the single-digit percent range. Though this marijuana would have been grossly inferior to the imported stuff, it could still get someone high (Clarke and Merlin, 2013, p. 51-52). 

on cannabis, a widely circulated USDA pamphlet recommended the herbicide 2,4-D, one of the most popular weedkillers at the time (Mart, 2015, p. 93) ${ }^{15}$. Based on its known tendency to damage surrounding crops, 2,4-D was likely the chemical employed in Indiana. It was also a main component of Agent Orange, the chemical that the US Army used to defoliate huge swathes of the Vietnam jungle and that caused severe health problems amongst the Vietnamese population and American troops (Mart, 2015, p. 105-106).

41 The chemical was sprayed on feral cannabis all over the country, but explicit reports of its use come from Kansas, where county officials covered the cost of spraying and crews. In 1969, Governor Robert Docking proposed a new law that would declare cannabis a "noxious weed," freeing up more resources for spraying and other eradication initiatives (Great Bend Tribune, 1969). But in a rare move, a citizen's group the Riley County Fish and Game Association - actively opposed the plan on ecological grounds. The group's president, Ted Cunningham, argued that cannabis routinely grew among other weedy plants, so destroying it by force or chemicals would remove "prime types of cover which also provides food for wildlife." The harvesting of wild cannabis 
was "a social problem," the group maintained, and it instead proposed making the harvesting of feral cannabis plants illegal (Manhattan Mercury, 1969).

Despite Cunningham's informed argument, chemical eradication of cannabis continued in Kansas. In 1973, researchers from the state's Agricultural Experiment Station and Marijuana Steering Committee tried to head off the ecological argument against eradication, arguing that their recommendations "would produce no long term environmental hazards and would probably improve environmental quality in Kansas" Like the USDA, the researchers recommended 2,4-D as part of their strategic, multichemical, and multi-year approach to eradicating feral cannabis. Despite his assurances that it was safe, a former agronomist at Kansas State University who helped draft the recommendations warned farmers to "avoid drift damage to nearby susceptible plants... and don't spray on windy days." The researchers never articulated exactly how routinely dumping toxic chemicals in their communities would "improve environmental quality" (Salina Journal, 1973).

2,4-D wasn't the only herbicide applied to cannabis crops in the 1970s. Beginning in 1975, the US government helped the Mexican government destroy Mexican pot farms with paraquat, an herbicide that would kill a cannabis plant in one day. When American pot smokers found out about this program in the late '70s, it provoked widespread panic, as most of the nation's weed was still imported from Mexico. Even though the paraquat scare turned out to be entirely baseless - only a fraction of the annual Mexican crop was affected, and the chemical is rendered harmless upon combustion it galvanized domestic production, a trend that was already turning into a small cottage industry in the secluded hills of northern California (Johnson, 2017, p. 120-122).

\section{From Hills to Homes: The Evolution of Modern Cannabis Cultivation}

The first generation of pot growers in northern California were back-to-the-landers: hippies and other counter-culturalists who fled the cities to scrape out a more subdued and peaceful existence in nature. On makeshift homesteads, they grew scattered plots of cannabis for their own consumption, or to barter and share with neighbors. But as expenses mounted, some of these homesteaders realized they could sell marijuana to make ends meet. The US government's crackdown on Mexican marijuana, as well as the paraquat scare, made American cannabis desirable for the first time (Johnson, 2017, p. 106-108; Raphael, 1985; Brady, 2013).

This marijuana "cottage industry" soon became a fact of life in the hills of northern California and southern Oregon (Raphael, 1985; Johnson, 2017a, p. 122-127), helping fill the baggies of the nation's 20 million pot smokers (US Drug Enforcement Agency, 1985, p. 11). In the latter region, authorities estimated the value of the marijuana crop to be around $\$ 7$ million in 1978. By the mid-1980s, growers in northern California's Humboldt and Mendocino counties were raising annual crops with an estimated value between $\$ 300$ and $\$ 400$ million. The explosion of clandestine marijuana growth in California during the 1980s prompted state authorities to launch a state-wide eradication effort called the Campaign Against Marijuana Planting, or CAMP. Running each summer from 1983 through the present and using National Guard helicopters, CAMP pulled up hundreds of thousands of plants and made hundreds of arrests. The CAMP reports also 
document the increasing trend of growers cultivating on public lands, where there was a lower chance of detection. By 1989, a third of the 147,000 plants seized in CAMP raids were taken from federal and state lands ${ }^{16}$. These "trespass" growers employed a variety of ecologically destructive tactics, including the wanton dumping of pesticides and fertilizers, the diversion of natural streams for irrigation, and leaving huge piles of trash at grow sites (Miller, 2018, p. 13-68).

Illegal marijuana growth on California's public lands continues today and gets a lot of attention from scholars, journalists, and cannabis enthusiasts (Lee, 2012; Hecht, 2014; Brady, 2013; Raphael, 1985; Miller, 2018). But large-scale marijuana cultivation occurred in other states and played out in much the same way as it did in California. The same year that CAMP began raids on the West Coast, authorities in West Virginia launched a similar campaign, using aerial surveillance to spot marijuana crops in rugged hills and forests that closely resemble the terrain in northern California. In 1985, this campaign uprooted 15,739 plants, which authorities estimated was only "20 percent" of the state's total crop. Like their California counterparts, West Virginia marijuana farmers were "remnants of the 'back-to-the-earth' movement" (The Hour, 1985).

In Kentucky, marijuana was "as common as hair on a dog's back" during the 1980 s (Brock, 1981). Between 1982 and 1988, authorities took more than 3 million plants from Kentucky's clandestine pot grows (Heckel, 1988), dwarfing the total number of plants seized by CAMP over the same period ${ }^{17}$. Indeed, a single raid on three central Kentucky pot fields in 1986 yielded an astonishing 384,000 plants, more than CAMP took in any year prior to 2000 (Cropper, 1986). In Arkansas, the average illegal marijuana patch held more than 200 plants in 1982, and that year the US Forest Service destroyed $\$ 20$ million worth of cannabis in the Ozark and St. Francis National Forests. The Forest Service estimated that there was still $\$ 200$ million worth of the crop to be found in the state (Montgomery, 1982).

These reports make clear that illegal marijuana cultivation was widespread anywhere the climate and geography supported it, not just in northern California's renowned "Emerald Triangle." Indeed, data from the Drug Enforcement Agency in 1985 shows "high occurrence" of marijuana farming across the South, Midwest, and West Coast. The agency also reported that authorities in forty-eight states were participating in federally sponsored eradication campaigns, and that these campaigns destroyed a total of 13 million plants in 1984 (US Drug Enforcement Agency, 1985, p. 2-3).

By the late 1980s, ramped-up state and federal enforcement campaigns made growing pot outdoors extremely risky. Accordingly, the nation's marijuana growers moved inside, to cultivation "labs" with grow lights and other sophisticated equipment. Reports of indoor growing become extremely numerous after 1989, and they describe cannabis being grown in basements, aquariums, apartments, and greenhouses (Baxter Bulletin, 1989; Hershberg, 1994; Franceschina, 2001; Moroney, 2003). ${ }^{18}$ By the time California became the first state to re-legalize marijuana for medicinal use in 1996, indoor growing was the established norm for America's cannabis cultivators (Hecht, 2014; Johnson, 2017a, p. 136-139). Thus, it should come as no surprise that when Colorado and Washington state re-legalized the adult use of marijuana in 2012, officials in both states generally ignored cannabis's long history as an outdoor crop, preferring instead to craft regulations that privileged energy-guzzling indoor cultivation (Johnson, 2017a, p. 153-156). 
50 As of December 2018, cannabis is entirely legal in ten states, while an additional twenty-three allow production for medical purposes. Though most marijuana is still cultivated indoors, the legal cannabis industry is gradually moving toward a model that includes more greenhouses and open-air grows. From Colorado to Kentucky, the longlost American hemp industry is also being revitalized, and Congress recently lifted the national ban on hemp farming. Of course, cannabis cultivation also continues in states that disallow its use.

\section{Conclusions}

51 Though the environmental history of cannabis proceeded more or less along the same trajectory in most parts of the country, there are some important regional distinctions. In the Midwest, for example, the plant embedded itself within a strong agricultural tradition, alternating between the boon and bane of Midwestern farmers, and appearing in greater quantities in the wild than almost anywhere else. With the exception of Kentucky and the major cities, cannabis cultivation and use was apparently far less common in the South, at least until the 1960s. In the West, illegal marijuana farmers in the 1930s, '40s, and '50s laid the foundation for the surge of domestic cultivation that swept the entire nation beginning in the 1970 s.

Despite these distinct regional experiences, geography appears to be a non-factor in many hallmarks of US cannabis history, including the appearance of wild cannabis, its illegal cultivation in forests, farms, hills, and public lands, and its proliferation indoors from the 1990s through the present. At the same time, authorities' response to the diffusion of cannabis remained remarkably similar across time and space; they enacted local laws and drives to stamp out its use and cultivation, routinely called on the public (as well as toxic chemicals) to assist these efforts, and associated cannabis with minorities and young people in order to accentuate its danger to American communities. And as tirelessly as cops, lawmakers, and some citizens worked to contain its spread, people and nature thwarted them at every turn: immigrants, transients, and musicians ferried plants and seeds from town to town and region to region; birds and the wind carried seed across the country; and nearly every feature of human civilization - roads, fences, fields, vacant city lots, farms, ditches, river banks, basements, homes, and apartments - seemed to offer a perfect place for these seeds to settle and thrive.

So while it is tempting to take at face value reports claiming that cannabis was introduced by Mexicans or that it was smoked only among youth, "negro districts," or hippies, and while it might make sense that cultivation is a unique feature of sunny California or the hempen hills of Kentucky, a broader, more environmentally focused history reveals, if nothing else, this: cannabis was and remains a crop of the masses, a plant whose usefulness is continually reasserted and reinforced by different people and cultures across time and space. Whatever the nature of people's claims, warnings, and experiences with cannabis, it was and is a plant of, by, and for the people - a true American weed. 


\section{BIBLIOGRAPHY}

Abel E.L., 1982. Marijuana on Trial: The Panama Canal Zone Report. International Journal of the Addictions, vol. 17, $\mathrm{n}^{\circ}$ 4, p. 667-678.

Asheville Citizen-Times, 1944. America Learns To Produce Own Hemp From Rope. January 27. Atlanta Constitution, 1935. Marijuana Drive Planned in State. March 20.

Bakersfield Californian, 1938. \$2,000 Marijuana Seized, 2 Men Held. October 3.

Baxter Bulletin (Mountain Home, AR), 1989. Indoor Growing. July 6, p. 4.

Beach B., 2016. Rumor and Libel: Regulating Cannabis in the Panama Canal Zone, 1914-1935.

Points: The Blog of the Alcohol \& Drugs History Society (blog).

Belvidere (IL) Daily Republican, 1943. Jensen Foreman of Darien Hemp Plant. June 25.

Billings Gazette, 1931. Rosebud Authorities Discover Marijuana. September 25.

Billings Gazette, 1935. Wyoming Officers Root Up Marijuana. August 8.

Brock H., 1981. Marijuana: “common as hair on a dog." Advocate-Messenger, Danville, KY, July 19, p. 1 .

Brown P., 1929a. Anti-Loco Bill Passed. Chicago Tribune, April 30.

Brown P., 1929b. Governor Kills Bill to Outlaw Machine Guns. Chicago Tribune, June 27, p. 12.

Angrosino, M.V., 2003. Rum and Ganja: Indenture, Drug Foods, Labor Motivation, and the Evolution of the Modern Sugar Industry in Trinidad. In Jankowiak W.R., Bradburd D., 2003. Drugs, Labor, and Colonial Expansion. Tucson, University of Arizona Press, p. 101-116.

Barcott B., 2015. Weed the People: The Future of Legal Marijuana in America. New York, Time Books.

Bonnie R.J., Whitebread C., 1974. The Marijuana Conviction: A History of Marijuana Prohibition in the United States. Charlottesville, University Press of Virginia.

Brady E., 2013. Humboldt: Life on America's Marijuana Frontier. London, Scribe Books.

Campos I., 2012. Home Grown: Marijuana and the Origins of Mexico's War on Drugs. Chapel Hill, University of North Carolina Press.

Campos I., 2018. Mexicans and the Origins of Marijuana Prohibition in the United States: A Reassessment. The Social History of Alcohol and Drugs, vol. 32 (2018), p. 6-37.

Chicago Tribune, 1927. 3 Arrests Bare Sale of Dope to Gary Students. December 19.

Chicago Tribune, 1929a. Ban on Hashish Blocked Despite Ravages of Drug. June 3, p. 20.

Chicago Tribune, 1929b. Gather Habit Forming Drug While the Legislature Delays Action. June 3, p. 46.

Chicago Tribune, 1944. Tax Financed New Industry To Be Shelved. January 20.

Chippewa Herald Telegram, 1938. Much Marijuana Grows Near Beloit. July 14

Chippewa Herald Telegram, 1945. Marijuana Rule Hits Hemp Farms. May 25.

Clarke R. C., Merlin M., 2013. Cannabis: Evolution and Ethnobotany. Berkeley, University of California Press. 
Council Bluffs Nonpareil, 1944. To Close 7 of Iowa's Hemp Plants. January 18.

Courier-Post, 1954. Fall in Hemp Prices May Curb Production. Camden, NJ, July 29, p. 12.

Cronon W., 1992. Kennecott Journey: Paths Out of Town. In Cronon W., Miles G., Gitlin J., Under and Open Sky: Rethinking America's Western Past. New York, WW Norton, p. 28-51.

Cropper C. M., 1986. Officers say trio of pot fields may be a record as task of destruction begins. Courier Journal, Louisville, KY, September 5.

Crosby A., 1972. The Columbian Exchange: Biological and Cultural Consequences of 1492. Santa Barbara, CA, Greenwood Publishing.

Daily Chronicle, 1944. Advertisement, War Hemp Industries, Inc. De Kalb, IL, August 7, p. 8.

Daily Press, 1939. Canaries and Dope. Newport News, VA, August 27, p. 6.

Des Moines Register, 1938. County to Declare War on Marijuana. May 25.

Des Moines Register, 1942. Tentative 1943 Farm Goals. December 2.

Denver Post, 1927. Smuggling of Mexican drug into Pueblo schools charged. February 18.

Dufton E., 2017. Grass Roots: The Rise and Fall and Rise of Marijuana in America. New York, Basic Books.

Duvall C., 2015. Cannabis. London, Reaktion Books.

Elie M., 2013. From Social History to Environmental History. And back?. RCC Perspectives vol. 5: Making Tracks: Human and Environmental Histories, p. 101-104.

El Paso Herald, 1915. Ordinance. June 4, p. 1.

Evans S., 2007. Bound in Twine: The History and Ecology of the Henequen-Wheat Complex for Mexico and the American and Canadian Plains, 1880-1950. College Station, Texas A\&M University Press.

Falck Z., 2010. Weeds: An Environmental History of Metropolitan America. Pittsburgh, University of Pittsburgh Press.

Ferraiolo K., 2007. From Killer Weed to Popular Medicine: The Evolution of American Drug Control Policy, 1937-2000. Journal of Policy History, vol. 19, n² 2, p. 147-179.

Fiege M., 2005. The Weedy West: Mobile Nature, Boundaries, and Common Space in the Montana Landscape. Western Historical Quarterly, vol. 36, $n^{\circ} 1$, p. 22-47.

Flores J.H., 2018. The Mexican Revolution in Chicago: Immigration Policies from the Early Twentieth Century to the Cold War. Champagne, University of Illinois Press.

Franceschina P., 2001. Residential homes fertile ground for pot. News-Press, Fort Myers, FL, March 18.

Gieringer D.H., 1999. The Forgotten Origins of Cannabis Prohibition in California. Contemporary Drug Problems, vol. 26, n 2, p. 237-288.

Globe Gazette, 1944. Says Hemp Plant to Open April 1. Mason City, IA, February 29.

Great Bend (KS) Tribune, 1969. County To Stop Wild Mary-Jane. April 6, p. 2.

Gutiérrez D.G., 1995. Walls and Mirrors: Mexican Americans, Mexican Immigrants, and the Politics of Ethnicity. Berkeley, University of California Press.

Hecht P., 2014. Weed Land: Inside America's Marijuana Epicenter and How Pot Went Legit. Berkeley, University of California Press. 
Heckel D., 1988. Police still sniffing out marijuana. Messenger-Inquirer, Owensboro, KY, July 25, p. 13.

Helena Independent, 1933. Mexican Marijuana Crop is Found by Miles City Police. August 2.

Herer J., 1985. The Emperor Wears No Clothes: Hemp and the Marijuana Conspiracy. A Ha Publishing.

Hershberg B., 1994. Man killed, brother hurt outside housing complex. The Courier Journal, Lexington, KY, March 7, p. 5.

Hopkins J.F., 1951. A History of the Hemp Industry in Kentucky. Lexington, University of Kentucky Press.

Hudak J., 2016. Marijuana: A Short History. Washington D.C., Brookings Institution Press.

Humboldt (IA) Independent, 1944. 11,000 Tons of Hemp Are Processed. August 29.

Indianapolis News, 1942. Sites for 5 Hemp Plants Selected. November 26.

Johnson N., 2017a. Grass Roots: A History of Cannabis in the American West. Corvallis, Oregon State University Press.

Johnson N., 2017b. Workers' Weed: Cannabis, Sugar Beets, and Landscapes of Labor in the American West, 1900-1950. Agricultural History, vol. 91, nº 3, p. 320-341.

Johnson N., 2018. Cannabis (marijuana). Colorado Encyclopedia.

King M., 1970. Marijuana Reapers Find 'Kentland Grass War' Is Still On. Courier-Journal, Louisville, KY, October 9, p. 7.

Kuzmarov J., 2009. The Myth of the Addicted Army: Vietnam and the Modern War on Drugs. Boston, University of Massachusetts Press.

Lafayette (IN) Journal and Courier, 1943. Remington Hemp Plant Progresses. July 29.

Las Vegas (NM) Daily Optic, 1933. Confiscate Marijuana. August 9.

Leader-Telegram, 1943. State Hemp Crop Four Times More Than Last Year's. Eau Claure, WI, August 5.

Lee M. A., 2012. Smoke Signals: A Social History of Marijuana ${ }_{20}^{[D}$ Medical, Recreational, Scientific. New York, Scribner.

Ludington Daily News, 1940. Seeks State-Wide Aid to Stamp Out Marijuana. July 31.

Lydon J., Teramura A.H., Coffman B.C., 1987. UV-B Radiation Effects on Photosynthesis, Growth and Cannabinoid Production of Two Cannabis sativa Chemotypes. Photochemistry and Photobiology, vol. $46, n^{\circ} 2$, p. 201-206.

Maddox T., 1943. Businessmen Farm Hemp. Cincinnati Inquirer, July 12.

Manhattan (KS) Mercury, 1969. Oppose Marijuana Plan. October 9, p. 1.

Marshfield (WI) News Herald, 1944. Ripon Group Trying to Keep Factory Running. March 4.

Mart M., 2015. Pesticides, A Love Story: America's Enduring Embrace of Dangerous Chemicals. Lawrence, University Press of Kansas.

McNeill J.R., 1992. Kif in the Rif: A Historical and Ecological Perspective on Marijuana, Markets, and Manure in Northern Morocco. Mountain Research and Development, vol. 12, n 4, p. 389-392.

McPartland J., 2017. Cannabis sativa and Cannabis indica versus 'Sativa' and 'Indica'. In Chandra S., Lata H., ElSohly M., 2017, Cannabis sativa L. - Botany and Biotechnology, p. 101-121. 
Merchant C., 2003. Shades of Darkness: Race and Environmental History. Environmental History, vol. 8, n 3, p. 380-394.

Miller C. (ed.), 2018. Where There's Smoke: The Environmental Science, Public Policy, and Politics of Marijuana. Lawrence, University Press of Kansas.

Minneapolis Star, 1938. The Legion vs Marijuana. May 21.

Montgomery D., 1982. Marijuana growing in Arkansas forests prove to be big problem for lawmen. Baxter Bulletin, Mountain Home, AR, July 28, p. 13.

Moroney J., 2003. METRICH raids net three. News-Journal, Mansfield, OH, February 15.

Mosk S.A., 1939. Subsidized Hemp Production in Spanish California. Agricultural History, vol. 13, $\mathrm{n}^{\circ} 4$, p. 171-175.

Nash L., 2007. Inescapable Ecologies: A History of Environment, Disease, and Knowledge. Berkeley, University of California Press.

News-Record (Marshall, NC), 1935. Gleanings from the Dailies. June 20.

Oshkosh (WI) Northwestern, 1939. Destroy Marijuana. January 13.

Parrish M.E., 1992. Anxious Decades: America in Prosperity and Depression. New York, W.W. Norton.

Pate D.W., 1983. Possible Role of Ultraviolet Radiation in Evolution of Cannabis Chemotypes.

Economic Botany, vol. 37, n 4, p. 396-405.

Pensacola News Journal, 1976. Weed Pickers Jailed (dateline Winamac, IN). September 30, p. 13.

Post-Crescent, 1945. Hemp Industry's Future Discussed at Confab. Appleton, WI, September 22.

Pueblo Chieftain, 1926a. Popular member of Central High Dies. October 25.

Pueblo Chieftain, 1926b. Funeral notices. October 27.

Quad City (IA) Times, 1939. Loco-weed in City Uprooted. January 15.

Raphael R., 1985. Cash Crop: An American Dream. Mendocino, CA, Ridge Times Press.

Rathge R., 2018. Mapping the Muggleheads: New Orleans and the Marijuana Menace, 1920-1930. Southern Spaces (blog).

Rendon J., 2012. Super Charged: How Outlaws, Hippies, and Scientists Reinvented Marijuana. Portland, OR, Timber Press.

Rubin V., Comitas L., 1976. Ganja in Jamaica: The effects of marijuana use. Garden City, NY, Anchor Press.

Sloman L., 1979. Reefer Madness: A History of Marihuana in America. New York, St. Martin's Griffin. St. Cloud (MN) Times, 1944. Hemp Plant is Swept By Fire. May 17.

St. Cloud (MN) Times, 1945. Group Working to Save Hemp Industry in Midwest States. August 9.

Stockberger W. W., 1919. Commercial Drug Growing in the United States in 1918. Journal of American Pharmaceutical Association, vol. 8, n 1, p. 809.

Stockberger W. W., 1915. Drug Plants Under Cultivation. Farmers' Bulletin, n 663. Washington, D.C., US Department of Agriculture.

Tennessean, 1936a. State's Lone Law Fails to Halt Sale of Marijuana Weed Here. April 16.

Tennessean, 1936b. Loco Weed Flourishes Untouchable by Law in Tennessee Field. April 25. 
Tennesean, 1942. Big Field of Marijuana Here Not For Smoking; It's Farmer's Contribution to US War Effort. October 18.

The Brook Reporter, 1944. Remington Hemp Plant to Be Sold. November 2.

The Hour, 1985. American marijuana now rivals imports (report from Charleston, WV). Norfolk, CT, August 28, p. 26.

The Pantagraph, 1945a. Future is Doubtful for the Hemp Crop. Bloomington, IL, November 15.

The Pantagraph, 1945b. Idle hemp Mill Paid \$775,665 To Lexington Farmers, Workers.

Bloomington, IL, November 25.

The Salina (KS) Journal, 1973. Progress made in marijuana eradication. April 3, p. 38.

The Saline Observer, 1938. Marihuana, Marijuana, Hemp; Hashish; Bhang. Saline, MI, August 18.

The Times, 1938. Act to Stamp Out Marijuana. Munster, IN, February 9.

The Times, 1930. Marijuana Farm Raided, Growing Product Seized. Shreveport, LA, July 31.

The Times Herald, 1944. Reviving U.S. Hemp Industry. Port Huron, MI, February 6.

Timmons, F.L., 2005. A History of Weed Control in the United States and Canada. Weed Science, vol. 53, p. 748-761.

True Republican, 1938a. Two Hundred Acres of Marijuana in the County. Sycamore, IL, September 14.

True Republican, 1938b. News of This County and Nearby Vicinity. Sycamore, IL, September 17.

True Republican, 1938c. Farmers Search for Marijuana in Corner of Fields. Sycamore, IL, September 21.

True Republican, 1940a. Keeps Up War on Marijuana. Sycamore, IL, July 23.

True Republican, 1940b. Winning Fight on Marijuana. Sycamore, IL, February 3.

United States Drug Enforcement Agency, 1985. Draft Environmental Impact Statement: Eradication on Non-Federal and Indian Lands in the Contiguous United States and Hawaii. Washington, DC, US Government Printing Office.

Warf B., 2014. High Points: An Historical Geography of Cannabis. Geographical Review, vol. 104, $\mathrm{n}^{\circ} 4$, p. 414-438.

Weekly Review, 1938. Opinion on Marijuana. Joliet, IL, September 28.

Woodland (CA) Daily Democrat, 1934. Yolo Marijuana Field Raided. September 7.

Worster D., 1979. The Dust Bowl: The Southern Plains in the 1930s. New York, Oxford University Press.

\section{NOTES}

1. In the early twentieth century, newspapers often inaccurately used "hashish" (also spelled "hasheesh") and "loco-weed" to refer to "marijuana"; "marijuana" is the psychotropic flowers of the cannabis plant, while "hashish" is resin collected from drug-producing cannabis varieties. "Loco-weed" refers to an entirely different plant, usually astragalus varieties (see Johnson, 2017a, p. 28-36).

2. The primary source base for this article is a collection of more than 1,500 newspaper reports from 32 states, spanning the entire twentieth century and into the twenty-first. These reports 
were procured during two major research periods between 2013 and 2018. The first period focused on the American West - defined as all the states west of the Dakotas, Nebraska, Kansas, and Oklahoma, including Texas, Alaska, and Hawaii - and included approximately 1,300 reports. The second, and far less expansive, research period focused on the Midwest - an area of eleven states, including Kansas, Nebraska, and Missouri - and the South/Appalachia region, an area of ten states, including the traditional Deep South as well as Kentucky and West Virginia. Approximately 300 news reports were taken from these two regions. Most of the news reports referenced in this article deal with illegal cultivation or wild growth; some are simply arrest reports, while others include a more general discussion of marijuana. The newspaper reports are supplemented by other sources, including state and federal reports and pamphlets that deal with illegal marijuana cultivation.

3. The Pharmacopoeia of the United States (Philadelphia, Lippincott, Grambo \& Co., 1851), 50.

4. In a trend that continues in some reporting today, most newspapers in the twentieth century took law enforcement's claims about marijuana at face value. Essentially, newspapers agreed for decades with the sentiment voiced by El Paso County Sheriff Stanley Good in 1915: "We officers have had the best opportunity to study the effects of the drug upon the human system" (El Paso Herald, 1915).

5. Statement of Dr. William C. Woodward, Hearings on H.R. 6385 before the Committee on Ways and Means, Seventy-Fifth Congress, May 4, 1937.

6. An out-and-out racist, Anslinger exaggerated marijuana's association with Mexicans and African Americans, as well as the effects of the plant itself, to argue that federal prohibition was urgently needed. He was helped in this regard by Mexican newspapers, which had produced a steady stream of articles about marijuana's alleged propensity to cause insanity and violence since the 1890s (Campos, 2012: 203-223). This sensationalist tack was picked up by American newspapers, which began blaming marijuana for all kinds of grotesque acts of violence. By amplifying the message of these articles and stoking fears that Mexicans, blacks, and the "criminal class" could easily hook children on drugs, the FBN chief was able to dominate the national perception of cannabis in the 1930s (Sloman, 1979: 52-64; Lee, 2012: 48-54).

7. Though he was not a sugar beet worker, "Jesus Hernandez" was arrested in Grand Junction, Colorado, in 1933 for growing 200 plants, a fairly large amount for the time (Las Vegas Daily Optic, 1933).

8. Statement of Hon. Ralph F. Lozier, Carollton, Mo., General Consul of the National Institute of Oilseed Products, Hearings on H.R. 6385 before the Committee on Ways and Means, Seventy-Fifth Congress, 1937, April 28.

9. For examples, see "Marijuana Grows Profusely on Vacant Lots in Marysville," The Marysville Advocate (KS), 1938, June 16; "Women Rotarians Hear Drug Chief," Indianapolis News, February 25, 1941; "Marijuana Grows Wild," The Sentinel (Carlisle, PA), 1936, September 8; "War on Marihuana," Escanaba Daily Press (MI), 1938, September 13.

10. Not only did the Midwest already have a strong agricultural tradition, but as one report from Indianapolis notes, "the well-cared-for corn fields of the Middle West offer the best soils for the production of hemp;" see "Hoosier Farmers Find New Crop Interest as Season for Hemp Harvest Approaches," The Indianapolis News, July 2, 1943.

11. Reports of domestic marijuana seizures fall off dramatically between 1941 and 1945 but become more common from 1946 onward. For a sampling of postwar marijuana activity in Denver, see "Denver Dope Ring Smashed," Denver Post, December 19, 1949, p. 1; John Snyder, "Raid Bares Huge Marijuana Cache," Denver Post, November 5, 1949, p. 1; Rolle Rand, "Arrest Bares Marijuana Traffic at Fitzsimons," Denver Post, July 23, 1947, p. 17. For activity in San FranciscoOakland, see "Four Arrested in Dope Raid," Oakland Tribune, November 19, 1947, p. 19, and "Dope Cache Found Here," Oakland Tribune, February 4, 1947, p. 1; for activity in Los Angeles, see "Dope Bootlegged in L.A. Like Speakeasy Drinks, Says Judge," Oakland Tribune, January 8, 1948, p. 3, 
"Sheriff Breaks Up Marijuana Ring," Oakland Tribune, December 18, 1946, p. 15, and "Reefer Habit Hops Up in America," Bakersfield Californian, September 9, 1948, p. 12; See "US, City Officers Push Drive on Marijuana Ring," Denver Post, April 10, 1948, p. 1; See "Big Marihuana Crop is Seized at Mead, Colo.," Denver Post, June 12, 1946, p. 1; John Snyder, "Peddlers of Marijuana Lead Youth to Crime-Harvest Near for '48 Crop," Denver Post, July 18, 1948; "Marijuana Crop Planters Hunted," Oakland Tribune, July 28, 1948, p. 1; "Rancher Accused of Having \$200,000 Worth of Marijuana He Is Said To Have Grown," Corona (CA) Daily Independent, July 15, 1947, p. 1; Reports in this survey come from the Redlands Daily Facts, Bakersfield Californian, Hayward Daily Review, Oakland Tribune, Long Beach Independent, Corona Independent, Long Beach Press-Telegram, San Mateo Times, Pasadena Independent, Van Nuys News, and the Star News (Pasadena).

12. While the natural purposes of THC remain generally unclear, botanical studies suggest that the compound may have evolved to help preserve moisture, as a defense mechanism - similar to terpenes in that effect - (Clarke and Merlin, 51), or to protect its flowers from UV radiation (Pate, 1983; Lydon, Teramura, Coffman, 1987).

13. For reports attributing wild marijuana to the World War II hemp program, see "US Plans To Rip Up Marijuana," Orlando (FL) Evening Star, June 22, 1970, p. 9; Fred Pettit, "Marijuana? Destroy it!" Des Moines Tribune, October 25, 1954, p. 1, and "Find Marijuana Growing Wild," Journal Gazette (Mattoon, IL), January 27, 1951, p. 1. For examples of wild marijuana in the postwar Midwest, see "Arrest three men possessing marijuana," Manhattan (KS) Mercury, September 18, 1968, p. 13; "Marijuana Grows in City," (report from Cleveland, OH) Orlando (FL) Sentinel, June 27, 1958, p. 2; "Marijuana is Gary's Problem," The Call-Leader (Ellwood, IN), August 30, 1951, p. 6; Roy Campbell, "Big Marijuana Cache Found in Depot Locker," The Lincoln (NE) Star, November 5, 1955, p. 15.

14. In King, 1970, the Pulaski County sheriff is quoted saying his office sprayed feral marijuana with herbicide but stopped because residents complained about damage to surrounding crops.

15. US Department of Agriculture, "Wild Hemp (Marijuana): How to Control It" (Washington, DC: US Government Printing Office, July 1970). Another report from Illinois in 1960 notes that "512 acres were sprayed with a[n] herbicide," but does not specify which one; see "Marijuana Grows Wild in Illinois," Journal-Gazette (Mattoon, IL), August 10, 1960.

16. Campaign Against Marijuana Planting Final Reports, 1984-1987, available at http:// library.humboldt.edu/humco/holdings/CAMP.htm; For example, see CAMP Final Report, 1989 (Sacramento, CA: CAMP Headquarters, 1989), p. 9; National Guard helicopters are mentioned in Appendix E; Analysis of CAMP reports, 1983-1996 (prepared by author).

17. CAMP raids netted 758,526 plants between 1983 and 1988 .

18. Including the reports cited, research for this article revealed at least 25 reports of indoor cultivation after 1989.

\section{ABSTRACTS}

The illegal cultivation of cannabis in the United States has a long history, the weight of which is currently propelling a number of US states to legalize and regulate the plant after more than eighty years of outright prohibition. While each region has its own distinct history with the crop, this article outlines the history of cannabis cultivation in three parts of the country - the Midwest, South, and West - in an attempt to map out the driving social, economic, geographic, and environmental forces of illegal (and in some cases, legal) cannabis cultivation in the United States. Understanding how the US became one of the premier cannabis-growing regions of the 
world in the late twentieth and twenty-first centuries will help scholars pinpoint major themes in the world history of cannabis, such as its adoption and distribution by marginalized peoples, its transnational appeal in a globalized capitalist system, and how the plant embeds itself within the urban and rural ecology of human civilization. With a clearer picture of these themes, cannabis scholarship can better inform future studies, discussions, and public policy related to the plant.

\section{INDEX}

Keywords: marijuana, cannabis, agriculture, weed

\section{AUTHOR}

\section{NICK JOHNSON}

Nick Johnson, njohnson4189@gmail.com, independent historian and associate editor of the Colorado Encyclopedia, Colorado, USA. He recently published:

- Johnson N., 2018. Seizing the Initiative: A Short History of Direct Democracy in America. Process: a blog for american history, April 3. http://www.processhistory.org/johnson-ballot-initiatives/ - Johnson N., 2017. Grass Roots: A History of Cannabis in the United States. Corvallis, Oregon State University Press.

- Johnson N., 2017. Workers' Weed: Cannabis, Sugar Beets, and Landscapes of Labor in the American West, 1900-1946. Agricultural History, vol. 91, nº 3, p. 320-341. 